\title{
Representations and concepts of professional ethos among Swiss religious education teacher trainers
}

\author{
Andrea Rota ${ }^{a}$ and Petra Bleisch Bouzar ${ }^{b} *$ \\ ${ }^{a}$ Institute for the Science of Religion, University of Bern, Bern, Switzerland; \\ ${ }^{b}$ Didaktik der Ethik und der Religionskunde, Pädagogische Hochschule Freiburg, \\ Freiburg, Switzerland
}

Over the past two decades, the organisation of religious education classes in Switzerland has undergone profound reforms. Amid the increasing secularisation and pluralisation of the religious landscape, many cantons have introduced a compulsory course that falls under the responsibility of the state and is aimed at teaching basic knowledge about a variety of religions. These reforms have enabled a harmonisation of the syllabi for religious education across the country and have prompted the adaptation of teacher training programmes. Because of the many diverse social expectations surrounding these new courses and the diverse academic traditions in the field of religious education, however, a unified conception of these courses is still absent. In this article, we discuss the ongoing construction of religious education teachers' professional ethos within this fluid context. In particular, we discuss the perspective of teacher trainers on pragmatic questions concerning religious plurality and the place of teachers' and pupils' personal (religious) experiences in the classroom, and pay attention to different representations of 'religion' and distinct ideas regarding the purpose of these courses as they have a major impact on the professional attitudes expected from teachers.

Keywords: professional ethos; teacher trainers; Switzerland; concepts of religion; impartiality

\section{Introduction}

Over the last two decades, the organisation of religious education in Swiss public schools ${ }^{1}$ has undergone profound reforms (Jödicke and Rota 2010). Following the increasing secularisation and pluralisation of the religious landscape, the great majority of cantons (the states that comprise the Swiss confederation) have replaced confessional or interreligious faith education with a compulsory course on multiple religions that falls under the responsibility of the state. This change has led to considerable public and political debate. Today, however, this reorganisation of religious education classes is

*Corresponding author. Email: bleischp@edufr.ch 
broadly accepted in the public arena (Jödicke and Rota 2014). Moreover, the increasing institutionalisation of these courses has allowed the topic of religion to be included in the intercantonal school syllabi that have recently been developed for both French- and German-speaking cantons. In the meantime, many teacher-training institutions have adapted their curricula and training programmes to incorporate this new subject.

Despite the consensus surrounding the importance of these classes, however, their teaching outcomes and the didactic frameworks in which they are delivered are far from unequivocal. This situation is the result of both diffuse political aims and interests in the reform process (Rota 2015) and distinct academic perspectives and traditions in the field of religious education (Helbling et al. 2013). In this article, we discuss the impact of this fuzzy framework on representations of impartiality and "professional ethos ${ }^{2}$ with respect to the new discipline. Our focus does not lie on individual teacher's attitudes. Instead, we direct our analysis at the institutional level, drawing attention to arguments and interpretative patterns (Deutungsmuster) that support distinct normative expectations with respect to the teachers' impartiality. We look for these arguments and patterns in official syllabi and textbooks, and among teacher trainers.

In the Swiss context, there are only a few academic publications dealing with the specific professional ethos required of teachers who present religions in a non-religious way. ${ }^{3}$ An influential position is held by Monika Jakobs (2011). ${ }^{4}$ She proposed to transpose three principles of civic education $^{5}$ into the new classes: the prohibition against overwhelming the pupils, the duty to depict controversies and the recognition of diversity. Furthermore, she insisted on the importance of teachers being aware of their 'religious-worldview standpoint' through an autobiographical reflection. Quoting Hull (2000), she urged teachers to develop, among other things, a mature representation of the concept of God. The editors of the Journal for the Didactics of the Scientific Study of Religions, ${ }^{6}$ founded in 2015, held a contrasting standpoint. In the first issue, they argued that the criteria orienting the attitude and activities of teachers in the classroom should be in accordance with scientific knowledge and methods (Bleisch et al. 2015). ${ }^{7}$

In the light of these divergent views, we start from the assumption that different conceptualisations of a professional ethos depend on the way of conceiving the general orientation of the new lessons. In this respect, the classical distinction between 'learning about' and 'learning from' religion (e.g. Grimmit 2000) does not appear particularly helpful in pushing the reflection forward. On the one hand, the distinction between these two approaches is rarely perceived and problematised in textbooks, syllabi and political debates. More often than not, 'about' and 'from' are simply lumped together in opposition to a 'teaching (in) religion' perspective (Jödicke 2013). On the other hand, experts in the didactic field do not always agree on the boundaries between the two approaches. Indeed, the debates on this topic can be 
interpreted as attempts to restrict or broaden the concrete practice and attitudes of teachers deemed acceptable within the framework of the new classes. The matter at hand is nothing less than the limits of a 'non-religious' approach to religion in the classroom. For these reasons, these categories are not very fruitful for analysis. Thus, we avoid a priori classifications. Instead, we favour an inductive methodology that allows us to identify the categories and distinctions that structure our field of research. It is on this basis that we will explore how the representations of the religious education classes and the standards expected from the teachers are entangled.

The article is structured as follows. First, we briefly describe the historical development and legal regulation of religious education in Swiss public schools to highlight the main effects of the recent reforms on religious education. We then turn to the curricula and textbooks, comparing the general outlines of the courses and specific recommendations for teachers. In the main part of the article, we analyse the perspectives of teacher trainers in different cantons. Finally, in a systematic conclusion, we draw attention to various desirable teaching outcomes of religious education classes and the distinct ways of framing religion. We argue that these issues play major roles in defining the professional attitude expected from teachers, as they imply specific boundaries between 'religious' and 'non-religious' teaching.

\section{Historical and legal context}

Historically, the federal structure that characterises Swiss law and politics has prompted the cantonal school systems to autonomously develop different models of religious education. To a greater or lesser extent, the Catholic and/or Protestant churches were usually implied in the organisation of these classes (Bräm 1978). Since the late nineteenth century, however, a Constitutional clause protects pupils' freedom of religion, allowing them to be exempted from these courses. As stated in Article 15 of the Federal Constitution: 'no one shall be forced [...] to follow religious teachings'.

These historical arrangements have remained unquestioned for almost a century. Since the turn of the millennium, however, a wave of reforms across the country introduced radical changes. In the majority of the cantons, the departments of public instruction replaced the churches' key roles in the organisation of religious education classes. Accordingly, the departments - and not the churches - are responsible for the preparation of syllabi and for teacher training. As a result, the courses increasingly present a plurality of religious and (incidentally) non-religious worldviews. Against this backdrop, these lessons are no longer considered to be a 'religious education' in the sense of Article 15 of the Federal Constitution; rather, they are seen as courses on the topic of religions, to which the exemption clause does not apply. As a consequence, many cantons have made the new classes part of the compulsory curriculum of all pupils. 
This recent bottom-up convergence of the cantonal models has led to the inclusion of a course on different religions in the newest intercantonal syllabi for both major linguistic regions (French and German). ${ }^{9}$ In the French-speaking cantons, the Plan d'études romand (introduced in 2010) includes a course called Ethique et Cultures Religieuses (ethics and religious cultures; ECR). This course is part of the human and social sciences curriculum. In the German-speaking cantons, the Lehrplan 21, whose introduction is planned for 2015 to 2020, the topic of religion is part of a new school subject called Natur, Mensch, Gesellschaft (nature, mankind, society; NMG) in primary school and Ethik, Religionen, Gemeinschaft (ethics, religions, community; ERG) in secondary school.

\section{General guidelines}

\subsection{Intercantonal syllabi}

The general orientation of the ERC and NMG/ERG courses is very similar. Both curricula stress the secular character of the new classes and emphasise their different goals with respect to the religious instruction provided by other social institutions. Thus, the authors of the ERG curriculum stress that 'this is a lesson about religions, not instruction in a particular religion, which is the task of parents, churches and religious communities'. ${ }^{10}$ Similarly, the French-speaking syllabus maintains that 'the course is fundamentally distinct from an apologetic religious instruction (catechism) aiming at deepening a particular "faith". In fact, it is quite the opposite: The course 'is a place of information and factual knowledge about the great religious and humanist traditions of the world' (ECR).

The acquisition of knowledge is not, however, the only purpose of the courses. Within the framework of both syllabi, the pupils should learn to situate and develop their identity in an increasingly intercultural and interreligious context. They should also learn how to deal with the plurality of worldviews in a respectful and self-confident way. This would foster 'tolerance and recognition of religious and secular ways of life' and thus contribute 'to the freedom of religion and consciousness in a democratic society' (ERG).

According to the syllabi, reflection on moral values is also a part of the development of pupils' character. In the course, the children 'gain an understanding of [different] moral ideals (Wertvorstellungen) and ethical principles' (ERG). Thus, they become aware of their personal ethical values and develop a sense of ethical responsibility, while also learning to respect the values and convictions of others (ECR).

Drawing on this general orientation, the syllabus for the German-speaking cantons includes a list of recommendations for ERG teachers, some of which explicitly outline aspects of a professional attitude: 
(1) Teachers must respect the fundamental rights of pupils. This means in particular that religious practices and religious instruction in the school context are expressly prohibited. Furthermore, teachers must maintain an open, unbiased and non-discriminatory attitude towards all religions and worldviews and handle them in an impartial and non-judgmental way. Due to cultural and contextual reasons, thematic priority, however, should be given to Christianity.

(2) Teachers must avoid ascribing a particular religious identity to their pupils. They must be careful not to exploit or overwhelm pupils, for example, by expecting them to intervene as experts on their religious beliefs.

(3) Teachers must be aware of their personal worldviews (weltanschauliche Horizonte). They should be open and transparent and guide their pupils with a respectful and interested mindset towards encounters and explorations.

(4) Teachers must respect the pupils' private sphere. Pupils should be able to express their convictions and experiences, but cannot be required to do so.

Unlike the Lehrplan 21, the Plan d'études romand does not provide much information on the professional attitudes expected of ECR teachers, apart from the general prohibition of proselytising. Some indications on how the material should be taught, however, are provided in the textbooks.

\subsection{Textbooks}

In the French-speaking part of the country, all cantons except two use the teaching materials produced by the Lausanne-based publishing house ENBIRO/AGORA, at least in primary schools. ${ }^{11}$ In the introductory pages, the $\dot{A}$ la découverte des religions (Discovering Religions) series of textbooks, first published in 2002, presents the ethical principles of the publisher (e.g. ENBIRO 2002, VII-VIII). These principles can be considered to be indirect guidance for teachers and present many similarities with the recommendations in the ERG syllabus. From the outset, the editors reiterate the prohibition of proselytising. They also remind teachers of the need to be aware of their own convictions in order to treat other traditions with respect. Furthermore, teachers should maintain a critical distance vis-à-vis the interpretations of history provided by religious traditions, while avoiding all value judgements about them.

The textbooks of the same collection published after 2008 (e.g. ENBIRO $2011,9)$ further stress that teachers should respect the rights of all pupils to not express their beliefs or practices. They should also keep in mind that pupils might lack specific knowledge about their own religious traditions 
and that within one community, there are often different - and even conflicting - sensibilities on a given topic. In all cases, the primary rule is respect for different practices and beliefs.

In the German-speaking cantons, a popular textbook collection for teaching on different religions includes the volumes titled HimmelsZeichen (Heaven's Signs, Gattiker et al. 2008) and FrageZeichen (Question Marks, Gattiker et al. 2009). Another established collection is called Blickpunkt (Point of View, Bernet et al. 2013; Pfeiffer et al. 2012; Zangger et al. 2013). ${ }^{12}$ The editors of both series agree on the necessity for teachers to provide 'objective knowledge' about different religions. This perspective is seen as important for complying with the Constitutional article protecting pupils' freedom of religion (Gattiker et al. 2008, 10; Pfeiffer et al. 2012, 9). The textbooks, however, present a different understanding of the subjects' general aim and the teachers' professional attitude.

On the one hand, the Blickpunkt textbooks consider religious education to be part of an education in general knowledge, addressing religious topics that pupils might encounter in their everyday lives. Drawing on constructivist learning theories, teachers should use this basis to broaden, diversify and systematise the children's concepts regarding religion. The textbooks explicitly state that the lessons are fact oriented and not an assessment of personal experiences or opinions. The authors also recognised, however, that the topic of religion is, 'by nature', prone to existential questioning. Teachers are reminded that their own convictions (or lack thereof) should not influence the discussion of these questions, which deserve particular sensitivity and impartiality. Moreover, the authors acknowledged that, despite their best effort to separate the learning process from the pupils' religious affiliation, the textbooks could affect their religious representations or those of their parents. Therefore, teachers should maintain an appropriate and respectful demeanour (e.g. Pfeiffer et al. 2012, 8-9).

On the other hand, HimmelsZeichen and FrageZeichen present themselves as 'interreligious manuals'. According to the authors, teachers should 'stay neutral' and avoid expressing their personal experiences or making any value judgements. The authors maintain, however, that '[r]eligious neutrality does not mean that the State (and therefore public schools) are totally devoid of religion or worldviews or that they deny or reject religiosity in society' (e.g. Gattiker et al. 2008; 10). Thus, teachers are advised to adopt a 'philosophical attitude' and use different religious traditions as possible interpretative solutions (Deutungsangebote) to the pupils' existential questions and experiences. More generally, when approaching religious plurality, teachers should encourage pupils to create their own religious representation while supporting them through their 'individual search process' (e.g. Gattiker et al. 2008, 18).

Up to this point, most of the general guidelines we have discussed deal with the so-called negative freedom of religion (Winzeler 2009, 24-34). 
This juridical term designs, in this context, the prohibition against forcing a religion upon the children. For the teachers, it also has other corollaries, often discussed in terms of 'respect' and avoidance of value judgements. Another aspect, however, emerges in the HimmelsZeichen and FrageZeichen collections. These textbooks emphasise the so-called positive freedom of religion, i.e. the right to have and express a religion. For the authors of the 'interreligious manuals', this right should not simply be passively granted in public schools. Rather, it implies an active, though not directive, effort of the teachers to foster the pupils' religious development.

To reach a more nuanced understanding of these distinct goals and their influence on the conceptions of teachers' professional ethos, we turn to the field of teacher training in the next section.

\section{Teacher training}

\subsection{The professionalisation of teacher training}

Since the middle of the nineteenth century, secular or religious cantonal teacher seminaries have been responsible for teacher training in Switzerland (Criblez, Hofstetter, and Périsset Bagnoud 2000). In the past 150 years, these institutions have undergone several transformations. The most recent one, starting in the 1990s, lead to their incorporation into the system of higher education, transforming them into academic colleges for teacher training (Pädagogische Hochschulen, Haute écoles pédagogiques). This framework introduced a stronger orientation towards both concrete professional practice and academic qualification (Ambühl 2010). In the German-speaking cantons, this evolution fostered the inclusion of subject-specific didactic courses in the curricula as important aspects of teacher training (Heitzmann 2013).

In the case of religious education, pastors and priests were traditionally responsible for providing content knowledge and some didactical suggestions. This situation has changed gradually since the 1980s. The introduction of the new courses for all pupils has increasingly led, in teachertraining colleges, to a specific basic training in subject-specific didactics.

Depending on the college, however, the content of the curricula and the time dedicated to this subject vary widely. The same is true for the academic qualifications of teacher trainers and their didactical orientations. Thus, it is still the responsibility of each teacher trainer to integrate content knowledge, didactical and pedagogical competencies and the syllabi's general recommendations to develop a professional ethos (see Tenorth 2006).

To account for this variety, between October and December 2014, we conducted four semi-structured interviews with teacher trainers from different institutions in both the French- and German-speaking regions of the country. Our interviewees teach specific courses on the didactics of religion at either a teacher education college or a university. Each is involved in the 
education of secondary school teachers, and some also contribute to training programmes for primary or high school teachers. In the next section, we compare the different viewpoints of the interviewees regarding the expected and transmitted professional attitudes of teachers. Due to limited space, we simplified their quite nuanced statements into a 'typical' form and used pseudonyms for each interviewee (i.e. Haas, Marti, Müller and Perrin). Drawing on our interviews, we highlight four main aspects that give shape to the outline of a professional ethos, with a special emphasis on teacher's impartiality.

\subsection{Outline of a professional ethos}

\subsection{1. 'Neutrality' and religious plurality}

The protection of the pupils' negative freedom of religion constitutes a shared starting point for our interviewees. All of them broadly agreed that religious education in public schools must have a non-discriminatory basis. Criticising or advocating a particular religion is clearly condemned. Teachers should avoid stereotypes and exoticism and, according to Müller and Perrin, not hide conflicts and tension within and among religious traditions. Although the concept of 'neutrality' is widely employed in political discussions to describe this attitude, teacher trainers overtly refrain from using this term because it wrongly suggests the possibility of discussing a subject without taking any standpoint (Marti). Furthermore, the school is characterised by asymmetric power relations between teachers and pupils (Haas); as an institution, public instruction carries certain social values (Müller) and aims to transmit a common culture (Perrin). Against this shared backdrop, however, our interviewees manifested different attitudes regarding the critique of particular religious traditions. While they all agreed that all general value judgements should be avoided, Müller maintained that school values (such as gender equality) should be used as a framework for questioning specific religious norms, practices and beliefs held by different groups. And in a similar way, religious morals could be used to question school values.

Our interviewees also found the idea of neutrality as a 'quantitative' equal treatment of all religions - for instance, in terms of the number of textbook pages or teaching hours devoted to each religion - to be very naïve. However, the issue reveals a fundamental tension. On the one side, a course on the topic of religion must take into account the current environment in which pupils live, where the influence of the Christian tradition is quite evident; on the other hand, the multicultural composition of society demands sensitivity to religious plurality. Marti considered that this situation requires the teachers to develop what he refers to as 'plurality skill' (Pluralitätsfähigkeit). He summed up this complex idea in four systematic aspects: 
- The sensibility for a non-homogeneous society (outer plurality),

- The awareness that no religious tradition is internally homogeneous (inner plurality),

- The acceptance of different positions, despite one's disagreement with them and

- The awareness of the relativity of one's truth.

According to Marti, this 'plurality skill' is among the most important aspects of a religious education teacher's professional attitude.

\subsubsection{Dealing with personal experiences concerning religion(s)}

There was a strong agreement among our interviewees concerning the influence of teachers' experiences with religion(s) and their disposition towards different traditions in their professional practice. Their experiences and attitudes influence the selection of topics and methods as well as their general orientation when depicting a particular religious tradition or religion in general. Therefore, teachers should cultivate a self-reflective posture. This general recommendation can, however, lead to different nuances.

According to Müller, teachers should be able to reflect on their own feelings towards different religious traditions and religiosity in general. Regardless of their individual religiosity or lack thereof, they must be deeply fascinated by the religious topic that they teach and approach it with a benevolent attitude. Without such a personal passion and dedication, the teachers would treat the topic in a detached way and thus fail to motivate the pupils. Conversely, for Haas and Perrin, self-reflection was an epistemic matter. Through the exercise of self-reflection, teachers should become aware of cognitive or emotional obstacles with respect to particular religions that could interfere with their professional practice. For instance, teachers should be capable of articulating their emotions when visiting a mosque as a form of self-knowledge (Haas). Through the discussion of their representations of religions during their training, teachers should be able to work on their conception of 'otherness' and thus avoiding imposing their views on their pupils (Perrin).

This issue is related to the question of whether teachers should share their own religious experiences and worldviews with their pupils. Our interviewees agreed that teachers' personal outlooks should neither be imposed nor censored. Instead, they insisted on the importance of teachers clarifying their intentions when discussing such matters with the pupils. The problem of answering questions related to teachers' religious beliefs or affiliations is a common example. The most appropriate way to answer such questions (including the possibility of not answering) depends on the context. Teachers should evaluate the purpose of the pupils' question in order to give an adequate answer. In this sense, Marti emphasised the antinomy that teachers 
confront: to determine the appropriate attitude in each specific situation, teachers must consider both the prohibition of indoctrination and the need for authenticity.

On a related topic, the teacher trainers also agreed that pupils' spontaneous statements regarding their own religious experiences or traditions should not be systematically discarded. But Müller warned that teachers should be careful to not lose the control of the lesson and its goals and content. As it is the case for teachers, pupils should also not be allowed to impose their views on their classmates.

\subsection{3. 'Religion' in religious education}

Referring to the Swiss Constitution, all of our interviewees agreed on the prohibition of proselytising. The aim of the courses is not to inspire religious feelings or to produce religious experiences. In this sense, enacting religious practices in the classroom is considered to be highly problematic. Our interviewees' opinions diverged, however, regarding teaching methods suitable for a religious education respectful of these limitations. The difficulty lies in that, according to our interviewees, religious education classes should not merely transmit factual knowledge about religions, they should also provide action-oriented instructional settings. With respect to this goal, different views emerged, in particular regarding the role of pupils' personal experiences and their interpretations of religion in the courses.

Referring to this debate, Müller argued in favour of teaching settings that require pupils to adopt the position of different religious traditions. These exercises, he maintained, might prove beneficial in understanding the diversity of the points of view. To further support his stance, he noted that protecting the pupils' freedom of religion must not interfere with the educational duty of public schools. Indeed, education constitutes another fundamental right of the pupils. The school must contribute to the development of pupils' personality and support them towards social maturity. Therefore, teachers should provide their pupils with the chance to reflect on the significance of different religious representations - for example, the four noble truths of Buddhism - for their lives. In this respect, he noted that in other school disciplines, such as German literature, it is quite usual to expect pupils to establish a personal relationship with the texts, and religious education may be the only discipline where this approach is controversial.

Marti also criticised the oversensitive attitude vis-à-vis similar teaching methods, which are very common in nearby disciplines, such as literature. According to his view, however, the goal of such approaches is not necessarily to invite pupils to engage with particular religious content. Rather, teachers should devise instructional settings that foster the discovery of religious phenomena in the pupils' near and far environments. Likewise, Haas 
emphasised that teachers should enable their pupils to situate different religious traditions, beliefs and artefacts in the world in which they live (Lebenswelt). Furthermore, they should be invited to reflect on their relationship with this reality. These observational and critical capacities constitute fundamental steps towards an autonomous assessment of religions that does not depend on the authority of parents, the media or religious leaders. In this sense, religious education classes have an emancipatory function.

Perrin also stressed the importance of discussing religion in context. But to her, putting religion into context means first and foremost placing religious data in a broader historical and anthropological framework. Through this exercise, teachers should foster pupils' sensitivity to the internal diversity of religious traditions and their capacity to recognise the variety of religious interpretations that have emerged through time and space. In her view, the appreciation of religion in one's local context - by visiting a religious building for instance - can be beneficial for teachers and pupils alike because it allows them to observe how religion is lived. It is also possible, however, that this type of experience will limit their understanding of a particular tradition to a single encounter. Finally, she acknowledged that teachers must also address pupils' existential and ethical questions that religious topics may provoke. To Perrin, however, this meant mitigating a 'strict' history-of-religions approach in the light of didactical considerations.

\subsubsection{The role of (scientific) knowledge}

Our interviewees all agreed on the importance of teachers mastering the fundamentals of didactics. An education science-based pedagogical knowledge is in their view an integral part of teacher training. Indeed, in this field, further research would be very much needed to evaluate different didactical practices. In particular, a greater knowledge of pupils' socialisation processes and basic research of subject-specific didactics is deemed important for fostering further professionalisation.

According to our interviewees, teachers should also have a broad knowledge of a variety of religious traditions. Their statements differed, however, on the relevant kind of knowledge. Perrin, Marti and Haas emphasised the role, for a professional teacher, of academic knowledge about different religious traditions and their imprints in culture. Perrin, in particular, noted that teachers must be able to contextualise both particular religious phenomena and specific experiences expressed in pupils' statements within the broader framework of the history of religion. For this reason, she strongly favoured the history of religions as a general frame of reference for selecting topics to cover in the courses and for evaluating the relevant statements expressed by pupils.

In a different perspective, Müller insisted on a hermeneutical understanding of religious traditions required from teachers in order to provide 
interpretative frames for the pupils. Accordingly, he affirmed that a science of religion approach cannot be the only reference in the classroom.

\section{Systematic discussion}

Among teacher trainers, as well as in syllabi and textbooks, there is a strong consensus regarding the need to provide religious education devoid of proselytisation. Thus, religious practice is considered inappropriate in the classroom. In general, teachers are expected to present different religions in an impartial way, refraining from blunt value judgements. Nevertheless, our interviews with teacher trainers revealed that the school is not perceived as a value-free space and that the transmission of certain normative orientations is a part of the teachers' duties. In this regard, 'neutrality' is discarded as a fruitless concept. Instead, a reflexive capacity and attitude are considered fundamental characteristics of teachers' professional ethos. It follows that teachers should not treat their individual (religious) views as exemplary nor should they repress them. Rather, they must be aware of their position on the topics discussed in the classroom in order to recognise their biases and prejudices. The capacity to reflexively adapt one's didactical practice to different situations according to the general aim of the course represents the keystone of teachers' professional attitude. Yet, precisely the general aim of the course appears to be an object of contention.

In a first step, we distinguished, on the basis of the general guidelines provided by syllabi and textbooks, distinct attitudes regarding the necessity of fostering the pupils' religious development. The juridical concepts of 'negative' and 'positive' freedom of religion served as reference for this distinction. The analysis of our interviews with the teacher trainers allowed us a more refined categorisation. Based on our data, we can analytically distinguish two teaching outcomes of a course on different religions: (1) the acquisition of knowledge and competencies needed to examine and understand religious practices, artefacts and beliefs and (2) the development of individual and social competencies with respect to religion. These two aims are not mutually exclusive, but imply different approaches to the subject matter. In the first case, teachers and pupils strive to understand the religious attitudes of a 'third' person or group by framing them in a broader social, historical and religious context. Conversely, in the second case, teachers invite pupils to examine and interpret this information to assess its relevance to their individual and social existence.

A second distinction, which cuts across the first one, is concerned with the locus of religion. Religion can be considered a human production that needs to be studied to understand social institutions, cultural practices and historical processes. Conversely, religion can be appraised as an anthropological constant that is independent of any particular religious tradition. As such, religion and worldviews are conceived in the broadest sense as a 
personal outlook on the world. According to this perspective, a particular religion becomes a resource to self-knowledge and may contribute to personal development.

In practice, these distinctions should not be understood as dichotomies. Rather, they represent two continuums that can be crossed in different ways. By combining these distinctions, we propose to construct three types that distinguish the different orientations of the courses. ${ }^{13}$ These types are as follows:

(1) Scientific orientation: This perspective is characterised by a focus on knowledge of religions as a fundamental learning outcome and conception of religion that is in line with the human and social sciences, thereby framing religion as a human and cultural production. Within this framework, a religion course provides an orientation within the scientific discourse concerning religion, society and culture.

(2) Social orientation: According to this perspective, religion courses focus on providing social orientation by fostering a reflection on pupils' relationships with their religious environments, as well as religious practices and artefacts they might encounter in culture and society. While pupils and teachers are encouraged to reflect on their attitudes towards different religious traditions as a means to foster individual and social competencies with respect to religion and religious people, religion itself remains an external object of study and is understood as a human, cultural production.

(3) Existential orientation: This approach combines an interest in the acquisition of individual and social competencies with a conception of religion as a fundamental dimension of all human beings. Therefore, particular religious content is understood as avenues for critical reflection and personal development. In this sense, the courses provide an orientation on an existential level by allowing pupils to assess the role of religious ideas, practices and artefacts in their own lives.

In the light of this typology, it is possible to observe how - despite some convergences on the prohibition of proselytising and the importance of a reflexive practice - conceptions of the professional attitudes expected from teachers might differ depending on the interactions between pedagogical goals and representations of religion. Thus, although it cannot provide a conclusive answer to the ongoing debate over the profile of a course that is respectful of pupils' freedom of religion (e.g. Bietenhard, Schmid \& Bleisch 2015; Frank 2010; Helbling et al. 2013), this categorisation might add fruitful nuances to the discussion by highlighting different representations and methods for relating religious topics to pupils' personal experiences. 


\section{Conclusion}

In this article, we showed that, following the recent reforms of religious education in Switzerland, the construction of a common representation of the professional attitude expected from teachers is an ongoing process. Drawing on data from syllabi, textbooks and interviews with teacher trainers, we argued that the central open issues concern the general orientation of the course more than they concern the pragmatic aspects of classroom life. Indeed, it is with respect to these orientations that similar practical indications and tasks can have widely diverging consequences. In particular, the general orientation of the course - which we defined as the intersection of the main pedagogical goal and the underlying representation of religion shapes the relation that teachers should foster between religious topics and pupils' experiences.

\section{Acknowledgements}

The authors would like to thank their interviewees for their time and expertise as well as the two anonymous reviewers for their insightful comments.

\section{Disclosure statement}

No potential conflict of interest was reported by the authors.

\section{Notes}

1. In Switzerland, the term 'public schools' is used to refer to publicly funded state-run schools.

2. Speaking of teachers, many authors have used the notion of 'professional ethos' with reference to the ethical or moral dimension of their profession (e.g. Oser 1991; Rodríguez-Sedano, Rumayor, and Paris 2011; Tirri 1996). Although this dimension plays an important role in our reflection, in this article, we use the term in a broader way to designate the attitudes and capacities expected from a teacher beyond fundamental technical skills. 'Impartiality' can be seen as a desirable part of a teacher's professional ethos. As an ideal set of practical, social and ethical qualities, the conception of 'professional ethos' has a clear normative dimension.

3. The term non-religious is used here to indicate a discourse on religion that is not itself religious. As we demonstrate later in this article, the line between religious and non-religious communication or teaching is a highly contended question.

4. See also Eva Ebel's article Professionsverständnis der Lehrperson (2015), which echoes Jakobs' position.

5. After heated debates in post-war Germany over principles and goals in civic education, various experts elaborated in 1976 the so-called Beutelsbacher Konsens. This consensus was based on three principles: the teachers must not overwhelm the pupils, controversies in politics and political science have to be depicted as controversies in the classroom and pupils should analyse specific political situations and bring their interests in the discussion (Sutor 2002).

6. Zeitschrift für Religionskunde - Revue de didactique des sciences des religions (http://www.zfrk-rdsr.ch). 
7. On the institutional level, further discussions were recently held during a workshop organised in January 2015 by the Association of Didactics Teachers for Religion, Ethics, and Culture. Drawing on a recent publication (Bietenhard, Schmid, and Bleisch 2015), the discussions focused on four main aspects: the need for a biographical self-reflection, the exemplar role of the teacher for dealing with religious diversity, impartiality and specific antinomies that teachers have to deal with (Bietenhard, Schmid, and Bleisch 2015).

8. Federal Constitution of the Swiss Confederation of 18 April 1999.

9. However, each canton can choose whether or not to use the intercantonal syllabi for this particular subject. Five out of seven French-speaking cantons use the ECR (Ethique et Cultures Religieuses) syllabus for at least a portion of their religion courses. The final version of the Lehrplan 21 was made publicly available only in September 2014. For this reason, the debate in the Germanspeaking cantons is still ongoing.

10. All citations from the syllabi were taken from their official websites: http:// www.plandetudes.ch and http://lehrplan.ch. All translations from German and French are the author's.

11. The publishing house was founded at the end of the 1960s with the name ENBIRO. In 2013, it changed its name to AGORA. The name change was meant to underscore its institutional separation from the Protestant and Catholic churches, which participated in its foundation.

12. HimmelsZeichen and FrageZeichen were initially developed for the primary school level in the Canton of Berne. Blickpunkt (three volumes) was initially developed for the Canton of Zurich for both primary and secondary schools.

13. A fourth combination might be theoretically possible, combining an acquisition of knowledge with the understanding of religion as a fundamental dimension of human beings. This combination might describe a classical doctrinebased teaching, like the catechism, and we could not find any plausible reference to it in our sample.

\section{Notes on contributors}

Andrea Rota is a postdoctoral assistant at the Institute for the science of religion at the University of Bern and senior researcher at the Chair for the study of religion at the University of Fribourg, Switzerland. He has done extensive research on the political debates surrounding religious education in Swiss public schools and the reactions they prompted among religious communities in the country.

Petra Bleisch is professor for didactics of ethics \& religion and head of the research unit 'Didactics of Ethics and Religion' at the teacher education college in Fribourg. She is co-editor of the journal 'Zeitschrift für Religionskunde - Forschung, Didaktik, Unterricht / Revue de didactique des sciences des religions' for didactics of non-confessional religious education in public schools and completed her $\mathrm{PhD}$ on narratives of learning processes among female Swiss Muslim converts.

\section{References}

Ambühl, Hans. 2010. "Zur Einleitung: Wie steht es um die Ziele, die mit der Tertiarisierung der Lehrerinnen- und Lehrerbildung verbunden waren?" In Tertiarisierung in der Lehrerinnen- und Lehrerbildung [Tertiary Development in Teacher Training], edited by Hans Ambühl and Willi Stadelmann, 14-21. Bern: Edk. 
Bernet, Marindanner, Schmid Hans, Senn Kuno, Zangger Prisca, Gschwend Michael, Kilchsperger Lars, R. Johannes, and Donatus Stemmle. 2013. Blickpunkt Religion und Kultur. Mittelstufe. Kommentar [Point of View Religion and Culture. Secondary School. Comment]. Zürich: Lehrmittelverlag.

Bietenhard, Sophia, Kuno Schmid, and Petra Bleisch. 2015. "'Lehrperson' und 'gute Lehre' in Ethik, Religionen, Gemeinschaft ['Teachers' and 'good teaching' in Ethics, Religions, and Community]." In Professionalisierung in den Fachdidaktiken [Professionalisation of Subject Specific Didactics], edited by Swissuniversities, 59-60. URL: http://www.swissuniversities.ch/fileadmin/swissuniversities/ Dokumente/DE/SWU/Forschung/Fachdidaktik/TagungFD2015_Dokumentation. pdf (July 1 2015).

Bleisch, Petra, Séverine Desponds, Nicole Durisch, and Katharina Frank. 2015. "Zeitschrift für Religionskunde: Begriffe, Konzepte, Programm / Revue de didactique des sciences des religions: notions, concepts, programme [Journal for the Didactics of the Scientific Study of Religion: Terms, Concepts, Programme]." Zeitschrift für Religionskunde - Forschung, Didaktik, Unterricht 1 (1): 8-26.

Bräm, Werner Kurt. 1978. Religionsunterricht als Rechtsproblem im Rahmen der Ordnung von Kirche und Staat [Religious Education as Juridical Problem with Respect to Church-State Relations]. Zürich: TVZ.

Criblez, Lucien, Rita Hofstetter, and Danièle Périsset Bagnoud, eds. 2000. La formation des enseignant(e)s primaires: histoire et réformes actuelles [The Training of Elementary School Teachers: Historical Aspects and Contemporary Reforms]. Bern: P. Lang.

Ebel, Eva. 2015. "Rolle und Professionsverständnis der Lehrperson [The Role and Professional Understanding of the Teacher]." In Ethik, Religionen, Gemeinschaft. Ein Studienbuch [Ethics, Religions, Community. A Study Book], edited by Sophia Bietenhard, Dominik Helbling, and Kuno Schmid, 156-163. Bern: Hep.

ENBIRO. 2002. Un monde en couleur. Méthodologie [A Colourful World. Methodology]. Lausanne: ENBIRO.

ENBIRO. 2011. Sur les traces d'Abraham. Méthodologie [Following Abraham's Footsteps. Methodology]. Lausanne: ENBIRO.

Frank, Katharina. 2010. Schulischer Religionsunterricht. Eine religionswissenschaftlich-soziologische Untersuchung [Religion Education in School. A Sociological and Study-of-Religion Perspective]. Stuttgart: Kohlhammer.

Gattiker, Susanne, Rosa Grädel, Jasmine Kiener, and Daniela Mühlethaler. 2008. FrageZeichen. Fragen aus dem Leben - Geschichten aus den Religionen. Hinweise für Lehrerinnen und Lehrer [Question Marks. Questions from Life - Stories from Religions. Guidelines for Teachers]. Bern: Schulverlag.

Gattiker, Susanne, Rosa Grädel, Jasmine Kiener, Daniela Mühlethaler, and Lisa Nyfeler. 2009. HimmelsZeichen. Geschichten aus den Religionen. Hinweise für Lehrerinnen und Lehrer [Heaven's Signs. Stories from Religions. Guidelines for Teachers]. Bern: Schulverlag.

Grimmitt, Michael. 2000. "Constructivist Pedagogies of Religious Education Project: Rethinking Knowledge, Teaching and Learning in Religious Education.” In Pedagogies of Religious Education, edited by Michael Grimmit, 189-207. Great Wakering: McCrimmon.

Heitzmann, Anni. 2013. "Entwicklung und Etablierung der Fachdidaktik in der schweizerischen Lehrerinnen- und Lehrerbildung: Überlegungen zu Rolle und Bedeutung, Analyse des Ist-Zustands und Reflexionen für eine produktive Weiterentwicklung [The Development and Institutionalisation of Branch Didactics in Swiss Teacher Training Programmes: Considerations on the Role and Meaning, 
Situation Analysis and Reflections for a Productive Development]." Beiträge zur Lehrerbildung 31 (1): 5-17.

Helbling, Dominik, Ulrich Kropač, Monika Jakobs, and Stephan Leimgruber. 2013. Konfessioneller und bekenntnisunabhängiger Religionsunterricht. Eine Verhältnisbestimmung am Beispiel Schweiz [Confessional and non-Confessional Religious Education. A Discussion of their Relations Based on the Example of Switzerland]. Zürich: TVZ Theologischer Verlag.

Hull, John M. 2000. Glaube und Bildung. Berg am Irchel: KiK Verlag.

Jakobs, Monika. 2011. "Grundlinien einer Didaktik für den bekenntnisunabhängigen Religionsunterricht." In 'Religion' lernen in der Schule. Didaktische Überlegungen für einen bekenntnisunabhängigen schulischen Religionsunterricht im Kontext einer Didaktik des Sachunterrichts [Learning 'Religion' in School. Educational Reflections for a non-Confessional Religious Education with Respect to the Didactics of General Primary Education], edited by Kuno Schmid, 70-103. Bern: Hep.

Jödicke, Ansgar. 2013. "Kantonale Entwicklungen beim schulischen Religionsunterricht und die Folgen für die Religionsgemeinschaften [Cantonal Trends in Religious Education and Their Consequences for the Religious Communities]." In Konfessioneller und bekenntnisunabhängiger Religionsunterricht. Eine Verhältnisbestimmung am Beispiel Schweiz [Confessional and non-Confessional Religious Education. A Discussion of their Relations Based on the Example of Switzerland], edited by Dominik Helbling, Ulrich Kropač, Monika Jakobs, and Stephan Leimgruber, 5-19. Zürich: TVZ Theologischer Verlag.

Jödicke, Ansgar, and Andrea Rota. 2010. "Unterricht zum Thema Religion an der öffentlichen Schule [Teaching on the Topic of Religion in Public Schools]." http://www.nfp58.ch/files/downloads/JoedickeSchuleSchlussberichtdef.pdf

Jödicke, Ansgar, and Andrea Rota. 2014. "Patterns of Religious Education Policy in Switzerland: The Long Arm of Distanced Christians?" Journal for the Scientific Study of Religion 53 (4): 722-738.

Oser, Fritz. 1991. Der Prozess der Verantwortung: berufsethische Entscheidungen von Lehrerinnen und Lehrern [The Process towards Responsibility. Teachers Decisions in the Domain of Professional Ethics]. Freiburg (Schweiz): Pädagogisches Institut der Universität.

Pfeiffer, Matthias, Kuno Schmid, Brigitt Gebs, Rahel Guyer, Laura Lüscher, Christine Schaufelberger, and Monika Schumacher-Bauer. 2012. Blickpunkt Religion und Kultur. Unterstufe. Kommentar [Point of View Religion and Culture. Primary School. Comment]. Zürich: Lehrmittelverlag.

Rodríguez-Sedano, Alfredo, Miguel Rumayor, and Ana Costa Paris. 2011. "The Formation of the Professional Ethos as a Factor of Integration Through the Virtues." Procedia Social and Behavioral Sciences 15: 1661-1666.

Rota, Andrea. 2015. Etat des lieux des politiques de l'enseignement religieux en Suisse latine: Réformes institutionnelles et schémas interprétatifs [Current Situation of Religious Education Policies in French- and Italian-Speaking Switzerland. Institutional Reforms and Interpretative Patterns]. Lausanne: Infolio.

Sutor, Bernhard. 2002. "Politische Bildung im Streit um die 'intellektuelle Gründung' der Bundesrepublik Deutschland [Political Education in the Conflict on the 'Intellectual Foundation' of the German Federal Republic]." In Bundeszentrale für politische Bildung (BPB) (2011). Beutelsbacher Konsens. Am 26. Januar 2015 bezogen von: http://www.bpb.de/die-bpb/51310/beutelsbacher-konsens. 
Tenorth, Heinz-Elmar. 2006. "Professionalität im Lehrberuf. Ratlosigkeit der Theorie, gelingende Praxis [Professionalism in Teaching. Theoretical Cluelessness, Practical Success]." Zeitschrift für Erziehungswissenschaften 9 (4): 580-597.

Tirri, Kirsi. 1996. "How Finnisch Teachers View Their Professional Ethos: A Case Study." Paper presented at the European Council for High Education, Vienna.

Winzeler, Christoph. 2009. Einführung in das Religionsverfassungsrecht der Schweiz [Introduction to Swiss Constitutional Law on Religion]. Zürich: Schulthess.

Zangger, Michael, Caroline Gritsch, Andrea Häusler Niederer, Thomas Staub, Mirjam Wolfangel, Johannes Beltz, Michel Bollag et al. 2013. Blickpunkt Religion und Kultur. Sekundarstufe I. Kommentar [Point of View Religion and Culture. Lower Secondary School. Comment]. Zürich: Lehrmittelverlag. 